\title{
$\mathrm{PAD}$ 법으로 제작된 산화코발트-산화주석 복합체의 가스 감응 특성
}

\author{
안세용 - 이위 · 장동미 · 정혁 · 김도진 ${ }^{\dagger}$ \\ 충남대학교 공과대학 재료공학과
}

\section{Cobalt Oxide-Tin Oxide Composite: Polymer-Assisted Deposition and Gas Sensing Properties}

\author{
Seayong An, Wei Li, Dongmi Jang, Hyuck Jung and Dojin Kim ${ }^{\dagger}$ \\ Department of Materials Science and Engineering, Chungnam National University, Daejeon, 305-764 Korea
}

(2010년 10월 21일 접수 : 2010년 11월 2일 최종수정 : 2010년 11월 2일 채택)

\begin{abstract}
A cobalt oxide - tin oxide nanocomposite based gas sensor on an $\mathrm{SiO}_{2}$ substrate was fabricated. Granular thin film of tin oxide was formed by a rheotaxial growth and thermal oxidation method using de magnetron sputtering of Sn. Nano particles of cobalt oxide were spin-coated on the tin oxide. The cobalt oxide nanoparticles were synthesized by polymer-assisted deposition method, which is a simple cost-effective versatile synthesis method for various metal oxides. The thickness of the film can be controlled over a wide range of thicknesses. The composite structures thus formed were characterized in terms of morphology and gas sensing properties for reduction gas of $\mathrm{H}_{2}$. The composites showed a highest response of $240 \%$ at $250^{\circ} \mathrm{C}$ upon exposure to $4 \% \mathrm{H}_{2}$. This response is higher than those observed in pure $\mathrm{SnO}_{2}(90 \%)$ and $\mathrm{Co}_{3} \mathrm{O}_{4}(70 \%)$ thin films. The improved response with the composite structure may be related to the additional formation of electrically active defects at the interfaces. The composite sensor shows a very fast response and good reproducibility.
\end{abstract}

Key words polymer-assisted deposition, gas sensor, Tin oxide, composite.

\section{1.서 론}

가스 센서는 대상 가스의 검출 방식에 따라 반도체식 가 스 센서, 접촉 연소식 가스 센서, 고체 전해질식 가스 센 서와 전기 화학식 가스 센서로 구분된다. 이 중 $\mathrm{ZnO}, \mathrm{SnO}_{2}$, $\mathrm{WO}_{3}, \mathrm{TiO}_{2}, \mathrm{In}_{2} \mathrm{O}_{3}$ 등과 같은 반도체식 금속산화물(semiconducting metal oxide)을 감지체로 활용하는 가스 센서 가 비교적 높은 감도와 저비용, 제작의 용이성, 실리콘 미 세공정과의 적합성등과 같은 유리한 측면 때문에 많은 주 목을 받아왔다..$^{1-6)}$ 이러한 반도체식 금속산화물 가스 센서 는, 가스에 노출되었을 때 $\mathrm{O}^{2-}, \mathrm{O}^{-}$혹은 $\mathrm{O}_{2}{ }^{-}$와 같은 흡 착 이온과 검출대상 가스 분자 사이의 상호작용에서 일 어나는 금속 산화물 층의 전기 저항 변화 현상을 활용하 여 작동한다.

이러한 금속산화물 중에서 특히 산화주석 $\left(\mathrm{SnO}_{2}\right)$ 은 $3.6 \mathrm{eV}$ 의 넓은 에너지 밴드갭을 갖는 n-형 화합물 반도체로서 암 모니아 $\left(\mathrm{NH}_{3}\right)$, 일산화질소 $(\mathrm{NO})$, 암모니아 $\left(\mathrm{NH}_{3}\right)$, 수소 $\left(\mathrm{H}_{2}\right)$, 일산화탄소 $(\mathrm{CO})$ 와 같은 다양한 가스에 대한 검출 특성이 광범위 하게 연구되고 있다. $\mathrm{SnO}_{2}$ 계 가스 센서는 많은 가

Corresponding author

E-Mail : dojin@cnu.ac.kr (D. Kim)
스에 대해 민감하고 안정된 반응을 나타내지만, 가스 선 택성이 미흡하고 작동온도가 대개 비교적 높다는 문제 점이 있다. 최근에는 백금 $(\mathrm{Pt})$, 납 $(\mathrm{Pd})$ 과 같은 촉매 금속 입자를 이용하여 활성화 된 수소 이온의 비율을 높여 가 스 센서의 감도를 증가시키고자 하는 연구 또한 시도되 고 있으며, $7,8,10)$ 기존의 박막 및 후막형 금속산화물 가스 센서의 감지체의 단점을 극복하기 위하여 다양한 나노벨 트(nanobelt), 나노선(nanorod), 나노와이어(nanowire)와 같 은 비표면적이 매우 넓은 나노구조를 가스 센서의 감지 체로 이용하고자 하는 연구가 활발히 진행 되고 있다. ${ }^{7,8,11)}$

PAD (polymer-assisted deposition)법은 수용액을 이용 해서 금속산화물박막을 만들어낼 수 있는 방법으로 거 의 모든 종류의 금속산화물에 적용이 가능하며 무정형 (Amorphous), 다결정형(polycrystalline), 에피택셜형(epitaxial) 박막 등 다양한 구조의 금속산화물박막을 $10 \mathrm{~nm}$ 부터 수 백 $\mathrm{nm}$ 두께의 박막까지 자유자제로 제작할 수 있다. 또 한, 제조공정 및 비용이 비교적 간단하고 저렴할 뿐만 아 니라 넓고 불규칙한 표면에 대해서도 적용이 가능하기 때 문에 다른 공정들에 비해 효율적인 장점을 가지고 있다. ${ }^{12)}$

본 실험에서는 이러한 $\mathrm{PAD}$ 법의 장점을 이용하여 산 화주석 박막 위에 산화코발트 복합체 가스 센서를 제작 
하였으며 기존 박막형 산화주석과 산화코발트 가스센서 의 수소 가스 검출 특성을 비교 분석하여 산화코발트산화주석 복합체의 수소 가스 검출소자로의 활용 가능 성을 확인해 보고자 하였다.

\section{2. 실험 방법}

본 실험에서는 가스 센서를 제작하기 위한 기판으로 $\mathrm{SiO}_{2}$ 절연층이 $300 \mathrm{~nm}$ 두께로 성장된 $\mathrm{p}$-형 $\mathrm{Si}$ 기판을 사 용하였다. 전극 패턴은 새도우마스크(shadow mask)를 사 용하여 $\mathrm{DC}$ 마그네트론 스퍼터링 방법으로 백금 $(\mathrm{Pt})$ 전극 을 증착하였다. 전극 구조가 형성된 기판 위에 스퍼티링 방법을 이용하여 주석 금속막을 $100 \mathrm{~nm}$ 두께로 증착하 였다. $99.99 \%$ 순도의 주석 타겟(Tasco)을 이용하였으며, 스퍼터링 전에 챔버 내의 압력을 $2.5 \times 10^{-5}$ torr로 유지 시킨 후 증착 공정을 수행하였다. 스퍼터링 공정은 상온 의 아르곤(Ar) 분위기에서 이루어졌다. 증착 시킨 후 전 기로를 사용하여 RGTO (Rheotaxial Growth and Thermal Oxidation) ${ }^{13,14)}$ 방식으로 $400^{\circ} \mathrm{C}, \mathrm{N}_{2}$ 와 $\mathrm{O}_{2}$ 의 혼합 가스 분 위기에서 2시간 동안 산화 공정을 실시하여 산화주석 박 막을 제작하였다. $\mathrm{PAD}$ 법으로 코발트 복합체를 제작하기 위해 황산코발트 $\left(\mathrm{CoSO}_{4} \cdot 7 \mathrm{H}_{2} \mathrm{O}\right.$, Aldrich)와 PEI (polyethylenimine, Aldrich)를 $30 \mathrm{ml}$ 의 증류수에 넣고 초음파 처 리하여 혼합 용액을 만들었다. ${ }^{15)}$ 이 혼합 용액을 $\mathrm{SiO}_{2}$ 기 판과 산화주석 박막 위에 스핀코터(spin-coater)를 사용하 여 $2000 \mathrm{rpm}$ 의 속도로 30 초간 도포한 뒤 $500^{\circ} \mathrm{C}$ 에서 2
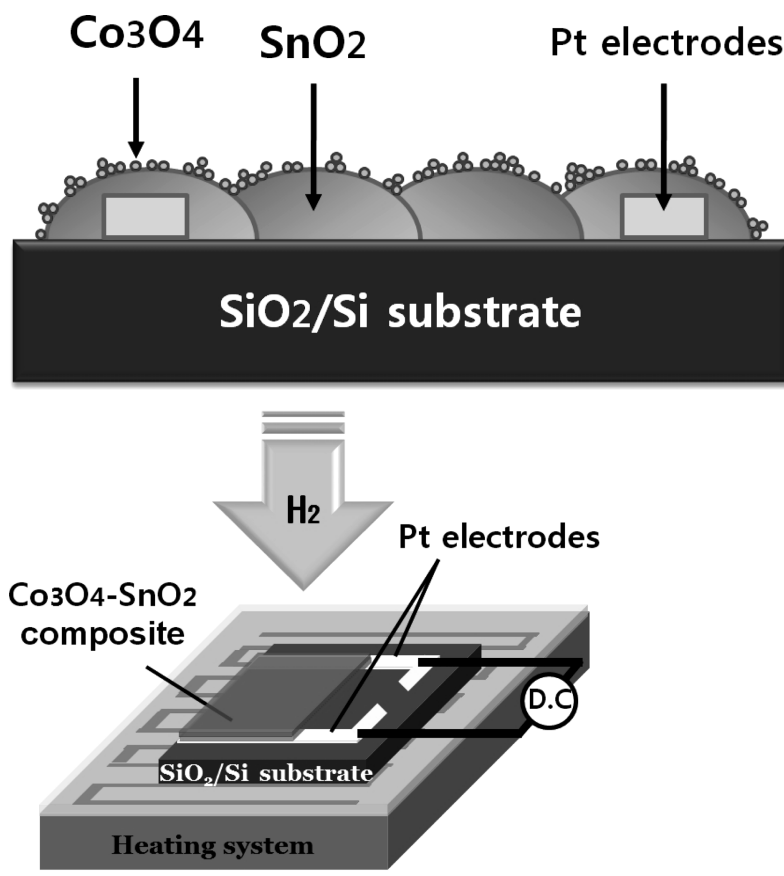

Fig. 1. Schematic diagram of the fabricated sensor morphology and the sensor measurements configuration.
시간 동안 열처리 공정을 수행하여 산화코발트 박막 및 산화코발트-산화주석 복합체 가스 센서를 제작하였다.

복합체의 표면 형상은 주사전자현미경(scanning electron microscope, $\mathrm{SEM}$ )을 이용하여 관찰하였으며, 가스 감응 특성은 Fig. 1의 센서 모듈에 의해 측정하였다. 제작된 가스 센서를 챔버 내에 위치시키고, Gold wire를 이용하 여 전극과 측정장비를 연결하였다. Dry air를 이용하여 수 소 가스의 농도를 $0.2 \%$ 에서 $4 \%$ 까지 조절하였고, 센서의 작동온도에 따른 감도 특성을 알아보기 위해 $150^{\circ} \mathrm{C}$ 에서 $300^{\circ} \mathrm{C}$ 까지 변화하였다. 수소 노출에 대한 가스 센서의 전 기적 반응 특성은 Keithely 2400(DC Bias Voltage Source, Current Measure Application)를 이용하여 측정하였으며, 측정된 센서의 감도(Sensor response)는 $\mathrm{S}(\%)=(\mathrm{Ra}-\mathrm{Rg}) /$ $\mathrm{Rg} \times 100$ 의 식에 의해 계산하였다. 여기서 $\mathrm{Ra}$ 와 $\mathrm{Rg}$ 는 각 각 희석가스 분위기에서의 센서 저항과 수소 가스 반응 시의 센서저항을 나타낸다. ${ }^{16)}$

\section{3. 결과 및 고찰}

\section{1 복합체의 형상}

Fig. 2(a)는 스퍼터링 방법으로 $100 \mathrm{~nm}$ 두께로 증착 된 주석의 주사전자현미경 사진이다. 조밀한 구조의 주석 박 막이 증착 된 것을 확인 할 수 있다. 산화 공정을 통해 형성된 산화주석의 미세구조는 Fig. 2(b)에서 보여지고 있 으며, 산화공정 중에 작은 산화주석 입자들이 응집으로 인해 거친 표면의 산화주석 박막이 형성된 것을 확인 할 수 있었다.

Fig. 2(c), 2(e)는 $\mathrm{SiO}_{2}$ 기판 위에 $\mathrm{PAD}$ 법으로 제작된 산화코발트의 사진이다. 혼합 용액 속에 들어가는 PEI와 황산코발트의 양이 증가함에 따라 기판 위의 코발트 입 자들의 분포가 많아지는 것을 볼 수 있었으며, 입자의 크 기가 균일하고 크기가 약 $~ 10 \mathrm{~nm}$ 정도 되는 것을 확인 할 수 있었다. Fig. 2(f)는 스퍼터링 방법에 의해 제작된 산화주석 박막(Fig. 2(b)) 위에 PAD법을 이용하여 제작 된 산화코발트(Fig. 2(e)) 복합체의 사진인데 Fig. 2(b)의 산화주석 박막과 비교하여 표면의 형태만 조금 거칠어 졌 을 뿐 큰 변화는 관찰 할 수 없었다.

\section{2 가스 감응 특성}

산화코발트-산화주석 복합체의 수소 가스에 대한 감지 특 성을 박막형 산화주석, 산화코발트 센서와 비교하기 위해 다양한 수소 가스 농도 및 작동온도에서 측정하였다. Fig. $3(\mathrm{a})$ 는 주석의 두께가 $100 \mathrm{~nm}$ 인 산화주석 센서의 작동온 도에 따른 수소 농도 $4 \%$ 에 대한 저항 그래프이다. 환원 가스인 수소와 반응 시 산화주석의 경우 $\mathrm{n}$-형 반도성 물 질로 저항이 감소하는 것을 관찰하였다. 또한 센서의 작 

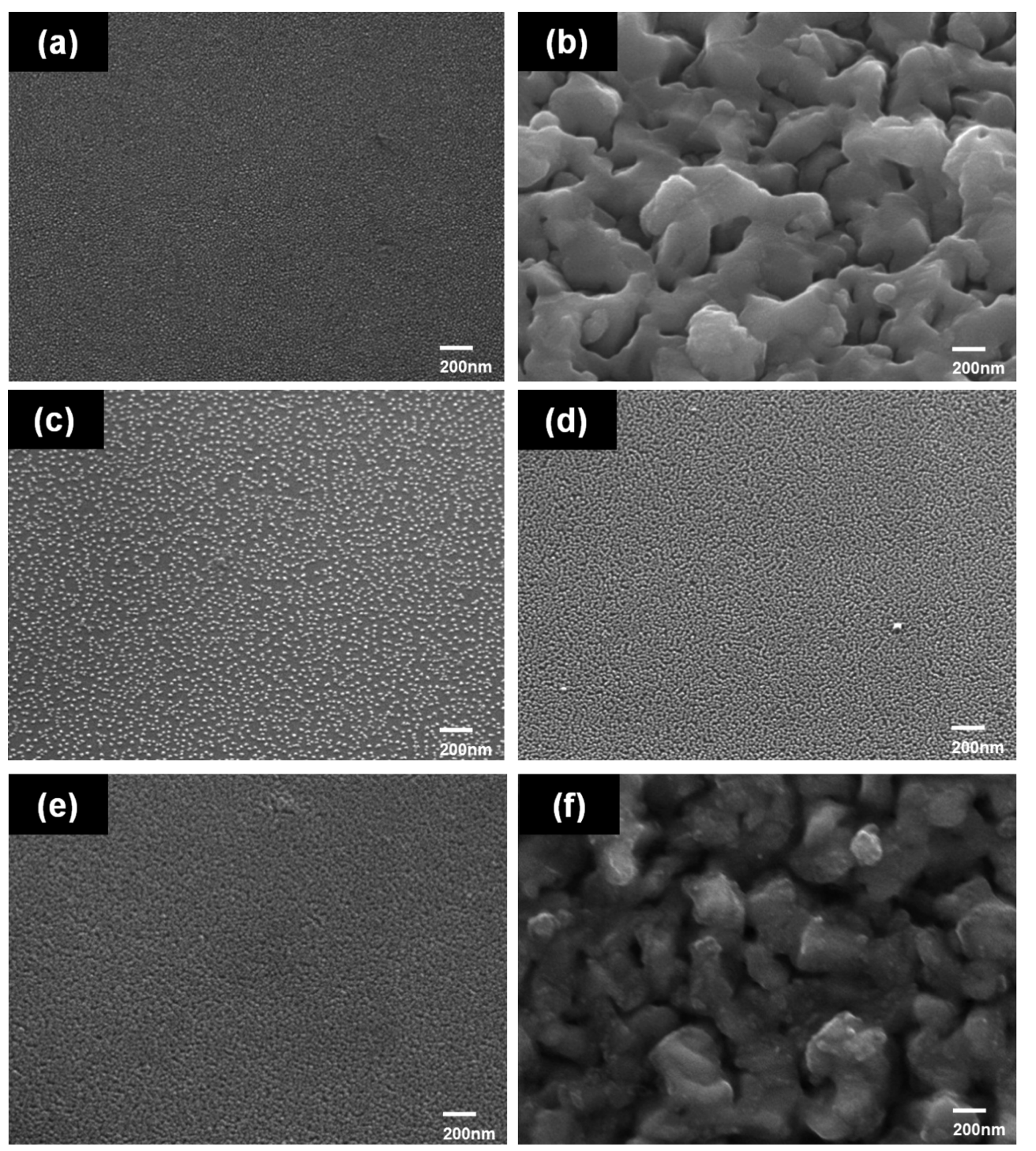

Fig. 2. The $\mathrm{SEM}$ images of (a) as-deposited $\mathrm{Sn}$ thin film $(100 \mathrm{~nm})$ on planar substrate by $\mathrm{DC}$ magnetron sputtering method, (b) $\mathrm{SnO}_{2}$ oxidized at $400^{\circ} \mathrm{C}$, (c), (d), (e) $\mathrm{Co}_{3} \mathrm{O}_{4}$ thin films prepared from different precursor solutions: $1.0 \mathrm{~g} \mathrm{PEI} / 0.1 \mathrm{~g}$ salt, $4.0 \mathrm{~g}$ PEI/ $0.4 \mathrm{~g}$ salt, $6.0 \mathrm{~g} \mathrm{PEI} / 0.6 \mathrm{~g}$ salt, respectively and (f) $\mathrm{Co}_{3} \mathrm{O}_{4}-\mathrm{SnO}_{2}$ composite.

동온도가 $200^{\circ} \mathrm{C}$ 이후부터 매우 안정된 반응 특성과 함께 초기 저항 상태로 회복하는 것을 확인 할 수 있었으며, 센서의 감도가 $250^{\circ} \mathrm{C}$ 에서 약 $90 \%$ 정도의 최대값을 갖 는 것을 확인 할 수 있었다.

Fig. 2(c)와 2(d) 같이 코발트 혼합용액의 농도가 낮아 서 기판 위에 형성되는 코발트 입자의 분포가 적을 경우 전기적 연결이 되지 않아 센서의 측정이 어렵다. 한편, 혼 합용액의 농도가 높은 Fig. 2(e)의 경우 연속적인 박막을 형성하므로 센서의 특성 측정이 가능하였고, 작동온도에 따른 $4 \%$ 수소 가스에 대한 측정결과를 Fig. 3(b)에 나타 내었다. 초기 저항은 약 $40 \mathrm{M} \Omega$ 정도로 일정한 값을 잘 유지하였으며 수소 가스에 노출되어 저항이 증가하는 것 을 확인 할 수 있었다. 이는 $\mathrm{p}$-형 반도체가 환원성 가스
를 감지하는 메커니즘과 같으며, 산화코발트가 $\mathrm{p}$-형 반도 체라는 것을 알려준다. 또한, 센서의 감도가 작동온도 $250^{\circ} \mathrm{C}$ 에서 약 $70 \%$ 정도로 최대값을 가지는 것을 확인 할 수 있었다.

대부분의 반도성 금속 산화물 센서의 가스 감지 메커 니즘은 감지체 표면에서의 가스 흡착과 탈착으로 인한 전 기 저항 혹은 전도도의 변화에 기반을 두고 있다. $\mathrm{SnO}_{2}$ 계 센서가 공기에 노출되었을 때, 대기 중의 산소가 $\mathrm{SnO}_{2}$ 의 노출 표면에 흡착하여 $\mathrm{SnO}_{2}$ 전도띠(conduction band) 로부터 전도 전자를 포획함으로써 $\mathrm{O}^{-}, \mathrm{O}^{2-}$ 혹은 $\mathrm{O}_{2}^{-}$이 온을 형성한다. 수소와 같은 환원성 가스에 노출되었을 때, 감지체 표면에서는 다음과 같은 흡착과 탈착 반응 을 통하여 전하를 교환한다. ${ }^{11,17)}$ 

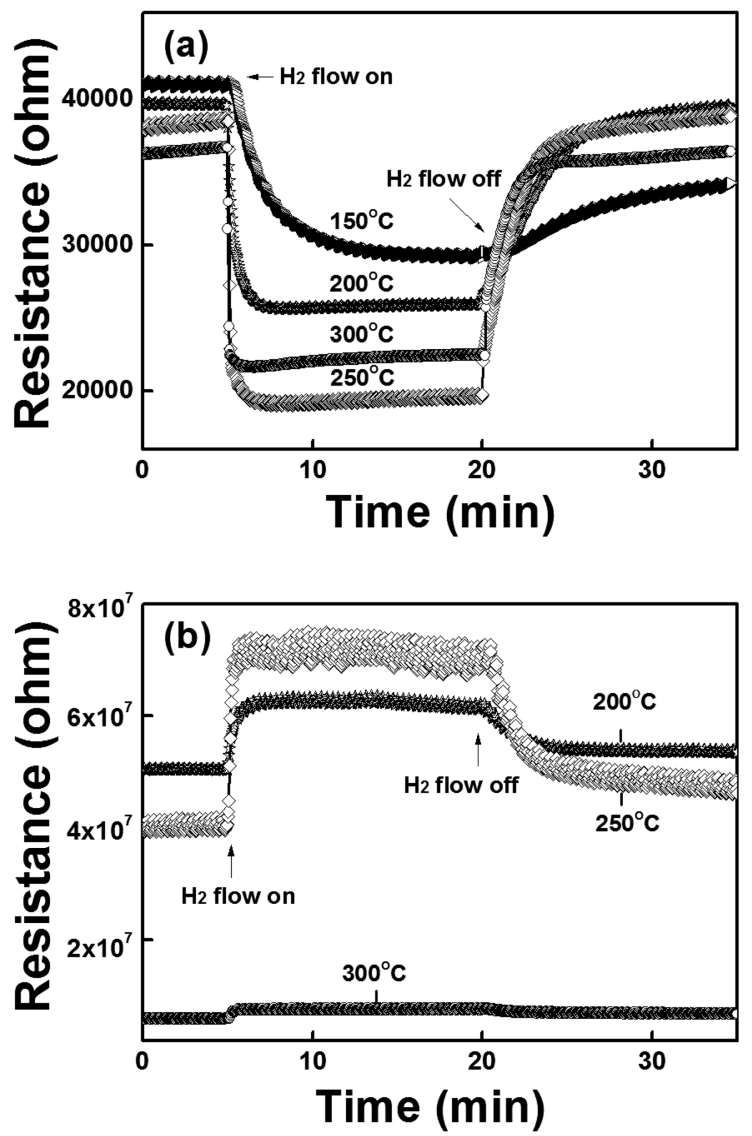

Fig. 3. Response and recovery curves of (a) $\mathrm{SnO}_{2}$ thin film, and (b) $\mathrm{Co}_{3} \mathrm{O}_{4}$ thin film sensor for $4 \% \mathrm{H}_{2}$ at different operating temperatures.

$$
\left.2 \mathrm{H}_{2}+\mathrm{O}_{2}^{-}{ }^{-} \text {ads }\right) \Leftrightarrow 2 \mathrm{H}_{2} \mathrm{O}+\mathrm{e}^{-}
$$

따라서, 감지체에 수소 가스가 주입되면 수소는 산소 와 반응하여 산화되고 표면의 산소종은 탈착된다. 이에 따라 산화주석은 빼앗긴 전자를 되받아 전기전도도는 증 가하게 된다.

산화코발트 박막은 전형적인 $\mathrm{p}$-형 반도성을 가지고 환 원가스와의 반응 시 저항이 증가(Fig. 3(b))하고, 반대로 산화주석 박막은 n-형 반도성을 가지고 저항이 감소(Fig. 3(a))한다. 그런데 산화코발트-산화주석 복합체 센서의 경 우 실제적으로 산화코발트의 입자보다 산화주석 박막의 영 향이 우세하여 수소 가스에 대해 n-형 반응성을 보이며 감지체로 작동함을 다음과 같이 확인할 수 있었다.

Fig. 4(a)는 $150,200,250$ 및 $300^{\circ} \mathrm{C}$ 네 가지 작동온도 에 따른 수소 농도 $4 \%$ 에 대한 복합체 센서의 반응곡선 을 보여준다. 센서의 반응특성이 작동온도에 민감하게 의 존한다는 점을 알 수 있었으며 작동온도가 높아짐에 따 라 센서의 초기저항이 낮아지는 현상은 반도체 특성에서 기인하는 것이다. 복합체 센서의 경우 작동온도가 $250^{\circ} \mathrm{C}$ 에서 저항이 $20 \mathrm{k} \Omega$ 정도로 박막형 산화주석 $(40 \mathrm{k} \Omega)$, 산
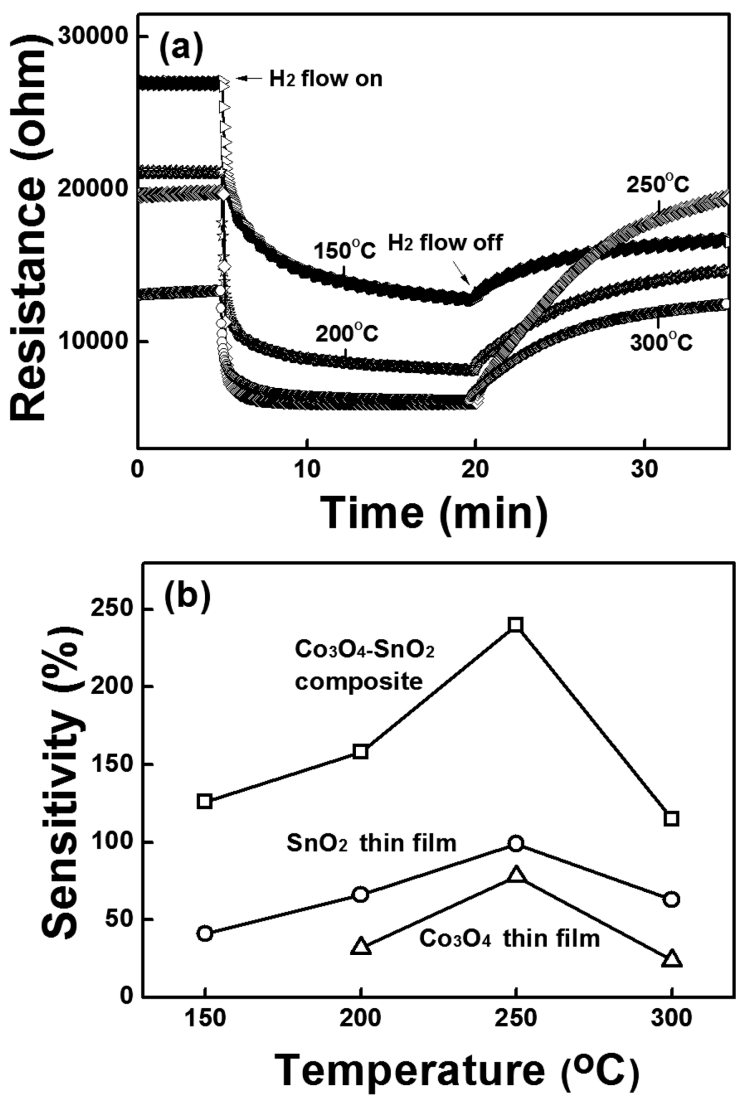

Fig. 4. (a) Response and recovery curves of $\mathrm{Co}_{3} \mathrm{O}_{4}-\mathrm{SnO}_{2}$ composite sensor upon exposure to $4 \% \mathrm{H}_{2}$ at different operating temperature, and (b) the response of $\mathrm{Co}_{3} \mathrm{O}_{4}, \mathrm{SnO}_{2}$ thin films and $\mathrm{Co}_{3} \mathrm{O}_{4}-\mathrm{SnO}_{2}$ composite to $4 \% \mathrm{H}_{2}$ at different temperatures.

화코발트 센서( $40 \mathrm{M} \Omega)$ 에 비하여 초기 저항이 낮은데 이 는 p-형 산화코발트와 n-형 산화주석의 p-n 접합 효과는 물론 두 저항의 병행 연결 모델로도 설명될 수 없는 결 과이다.

산화코발트 입자가 산화주석 표면에 붙으며 전기전도도 를 높일 수 있는 결함을 형성했을 가능성이 있으며 PAD 공정 후에 표면에 남아있는 화학종의 영향일 가능성도 있 으나 자세히 살펴봐야 할 문제이다.

센서의 감도가 $250^{\circ} \mathrm{C}$ 에서 약 $240 \%$ 정도로 최대값을 가 지는 것을 볼 수 있으며, 다른 온도와 비교하여 짧은 시 간에 매우 안정된 반응특성과 함께 초기 저항 상태로 회 복하는 것을 확인 할 수 있었다. 또한, 산화코발트 센서 (Fig. 3(b)) 보다 회복특성이 우수한데 이는 산화주석(Fig. $3(\mathrm{a}))$ 의 역할 때문으로 보인다. Dry air 분위기에 수소 농 도 $4 \%$ 에 대해 박막형 산화주석, 산화코발트 센서와 복 합체 센서의 가스 감도가 작동온도에 따라 변화하는 양 상을 Fig. 4(b)에 나타내었다. 산화주석, 산화코발트, 그리 고 산화코발트-산화주석 복합체 모두 작동온도 $250^{\circ} \mathrm{C}$ 에서 최대 감도를 보이며 복합체 $(240 \%)$ 가 산화주석 박막 $(90 \%)$ 과 산화코발트 박막 $(70 \%)$ 센서에 비해 전반적으로 감도 
가 향상된 것을 확인 할 수 있었다. 또한, 센서들의 작 동온도가 높아질수록 수소 가스에 대한 감도가 증가하 다가 낮아지는 것을 확인할 수 있는데, 이는 열적 활성 화의 증진으로 금속산화물 표면에 수소 가스의 흡착반응 이 향상되다가 온도가 높아져 흡착반응이 감소하여 전자 의 이동이 낮아지기 때문으로 판단된다. ${ }^{18,19)}$

산화코발트-산화주석 복합체 센서에 대한 수소 농도에 따른 감도 특성과 반복특성을 Fig. 5에 나타내었다. Fig. $5(\mathrm{a})$ 에서는 최적 작동온도 $250^{\circ} \mathrm{C}$ 에서 dry air에 의해 조 절된 $0.2 \%$ 에서 $4 \%$ 의 수소 농도에 따른 센서의 저항 반 응곡선으로 일반적으로 관찰되는 감지곡선의 형태임을 확 인할 수 있다. 센서의 초기 저항이 일정한 반면에 수소 가스에 노출되었을 때는 저항이 갑자기 감소하는데 이는 $\mathrm{n}$-형 반도체가 환원성 가스를 감지하는 메커니즘과 같아 서 $\mathrm{p}$-형 코발트 산화물의 영향은 나타나지 않고 있다. 농 도가 증가함에 따라 가스의 흡착 반응성 또한 증대되어 센서의 감도가 향상되는 것을 알 수 있었다. 최적 작동 온도에서 $4 \%$ 수소 가스 농도에 따른 반복특성을 Fig.
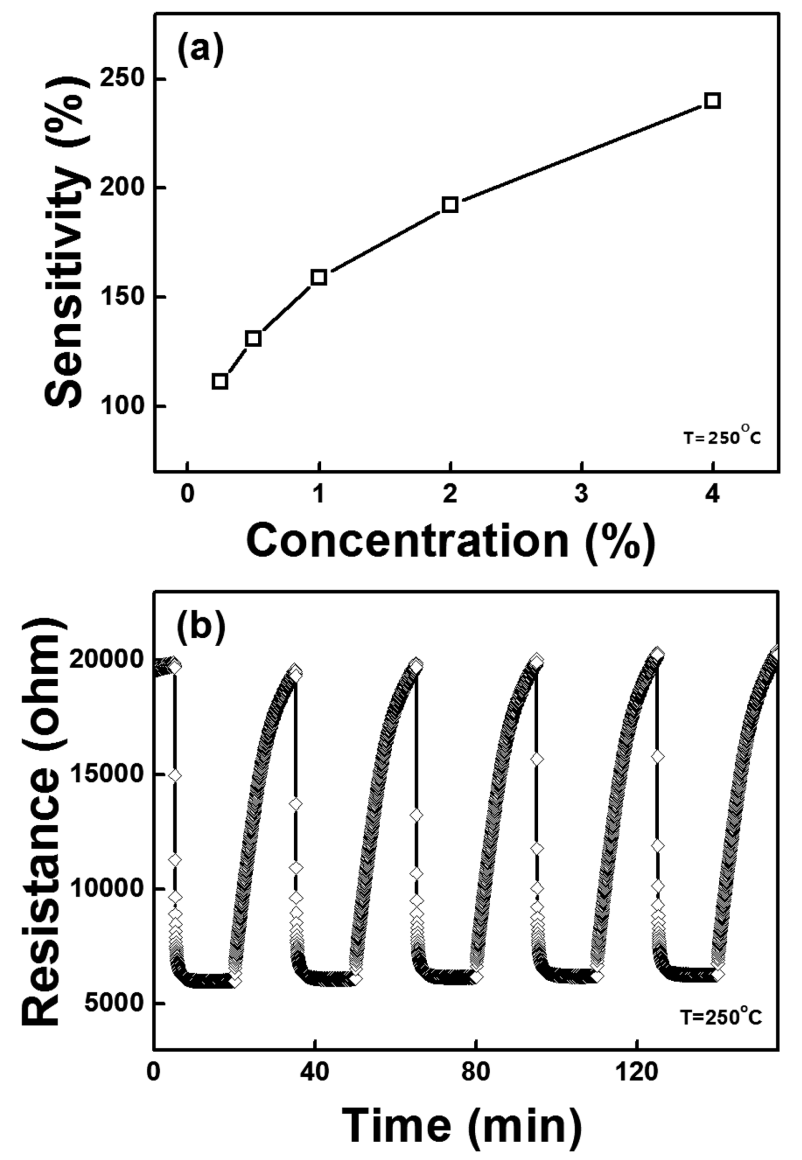

Fig. 5. (a) Response vs. $\mathrm{H}_{2}$ gas concentrations in dry air of the $\mathrm{Co}_{3} \mathrm{O}_{4}-\mathrm{SnO}_{2}$ composite sensor at an operating temperature of $250^{\circ} \mathrm{C}$, and (b) reproducibility test of the $\mathrm{Co}_{3} \mathrm{O}_{4}-\mathrm{SnO}_{2}$ composite for $4 \% \mathrm{H}_{2}$ at $250^{\circ} \mathrm{C}$ 5(b)에 나타내었다. 5 회 걸친 반복테스트 결과 약 $240 \%$ 정도의 감도에서 $3 \%$ 내외의 작은 변화를 보임으로써 매 우 안정된 감도를 보이며 센서의 우수한 반복특성 및 안 정성을 확인할 수 있었다.

\section{4. 결 론}

본 연구에서는 DC 마그네트론 스퍼터링 방법에 의해 제작된 산화주석 박막 위에 황산코발트와 PEI 혼합 용 액을 스핀코터를 사용하여 도포하는 $\mathrm{PAD}$ 방법을 혼합시 켜 산화코발트-산화주석 복합체 가스센서를 제작하는 방 법을 제안하고 있으며, 제작된 센서의 dry air 분위기에 서 환원성 가스인 수소의 감지특성을 조사하였다. 제작된 산화코발트-산화주석 복합체의 경우 상대적으로 산화 코 발트의 부피 비율이 작아서 전체적으로 산화주석의 $\mathrm{n}$-형 반도성을 띄는 감지체로 작동함을 확인할 수 있었으며 순 수한 산화주석 박막과 같이 최적 작동온도 $250^{\circ} \mathrm{C}$ 에서 짧 은 시간에 매우 안정된 반응특성과 회복특성을 보이는 것 을 확인 할 수 있었다. 산화코발트의 영향으로 복합체 형 태 센서구조의 감도 특성이 전반적으로 향상되는 결과를 확인 할 수 있었다.

\section{감사의 글}

본 연구는 한국과학재단 국가지정연구실사업(NRL), 그 리고 세계 수준의 연구중심대학(World-Class University, $\mathrm{WCU})$ 사업의 지원으로 수행되었습니다.

\section{참 고 문 헌}

1. J. X. Wang, X. W. Sun, Y. Yang, H. Huang, Y. C. Lee, O. K. Tan and L. Vayssieres, Nanotechnology, 17, 4995 (2006).

2. A. S. Zuruki, A. Kolmalov, N. C. Macdonald and M. Moskovits, Appl. Phys. Lett., 88, 102904 (2006).

3. H. Huang, O. K. Tan, Y. C. Lee, T. D. Tran, M. S. Tse and X. Yao, Appl. Phys. Lett., 87, 163123 (2005).

4. Y. S. Kim, S. -C. Ha, K. Kim, H. Yang, S. -Y. Choi, Y. T. Kim, J. T. Park, C. H. Lee, J. Choi, J. Paek and K. Lee, Appl. Phys. Lett., 86, 213105 (2005).

5. J. Y. Kim, B. G. Kim, S. H. Choi, J. G. Park and J. H. Park, Kor. J. Mater. Res., 20(4), 223 (2010) (in Korean).

6. N. L. Hung, H. J. Kim and D. Kim, Kor. J. Mater. Res., 20(5), 235 (2010) (in Korean).

7. H. T. Wang, B. S. Kang, F. Ren, L. C. Tien, P. W. Sadik, D. P. Norton, S. J. Pearton and J. Lin, Appl. Phys. Lett., 86, 243503 (2005).

8. L. C. Tien, H. T. Wang, B. S. Kang, F. Ren, P. W. Sadik, D. P. Norton, S. J. Pearton and J. Lin, Electrochem. Solid- 
State Lett., 8, G230 (2005).

9. N. D. Hoa, N. V. Quy, Y. S. Cho and D. Kim, Phys. Status Solidi A, 204, 1820 (2007).

10. K. D. Mitzner, J. Sternhagen and D. W. Galipeau, Sensor. Actuator. B Chem., 93, 92 (2003).

11. P. Mitra, A. P. Chatterjee and H. S.Maiti, Mater. Lett., 35, 33 (1998).

12. Q. X. Jia, T. M. McCleskey, A. K. Burrell, Y. Lin, G. E. Collis, H. Wang, A. D. Q. Li and S. R. Foltyn, Nat. Mater., 3, 529 (2004).

13. M. Radecka, J. Przewoznik and K. Zakrzewska, Thin Solid Films, 391, 247 (2001).
14. G. Sberveglieri, G. Faglia, S. Groppeili, P. Nelli and A. Camanzi, Semicond. Sci. Tech., 5, 1231 (1990).

15. W. Li, H. Jung, N. D. Hoa, D. Kim, S. -K. Hong and H. Kim, Sensor. Actuator. B Chem., 150, 160 (2010).

16. N. D. Hoa, N. V. Quy and D. Kim, Sensor. Actuator. B Chem., 142, 253 (2009)

17. A. Janotti and C. G. Van de Walle, Appl. Phys. Lett., 87, 122102 (2005).

18. H. Nanto, T. T. Minami and S. Takata, J. Appl. Phys., 60, 482 (1986).

19. G. Sakai, N. Matsunaga, K. Shimanoe and N. Yamazoe, Sensor. Actuator. B Chem., 80, 125 (2001). 